\section{Occurrence of urinary tract infection among children attending Gandaki Medical College Teaching Hospital and Research Center, Pokhara, Nepal}

\author{
Gautam G, ${ }^{{ }^{*}}$ Regmi S,1 Magar NT, ${ }^{1}$ Subedi \\ B, ${ }^{2}$ Sharma T, ${ }^{3}$ Regmi SM ${ }^{4}$
}

\footnotetext{
1,2 Department of Microbiology, Gandaki Medical

College Teaching Hospital and Research Center

Pvt. Ltd., Pokhara, Nepal, ${ }^{3}$ Department of

Medicine, Gandaki Medical College Teaching Hospital and Research Center Pvt. Ltd., Pokhara, Nepal, ${ }^{4}$ Post graduate student, Mahidol University, Thailand
}

*Correspondence to: Mr. Gautam Gyanendra, Department of Microbiology, Gandaki Medical College, Pokhara, Nepal, email: gautamgyanendrapokhara@ gmail.com, Tel. No.: (+977)-9856030915

\begin{abstract}
INTRODUCTION: Urinary tract infection (UTI) is considered as the most common bacterial infectious disease seen among the pediatric patients. Most commonly, members of Enterobacteriaceae, particularly uropathogenic strains of E. coli and Enterobacter spp. are the primary causative pathogens of UTI in the different part of the world. Emergence of antimicrobial resistance rates among pathogens recovered from urinary tract infections is an increasing problem in the specific region.
\end{abstract}

MATERIALS AND METHODS: Prevalence and anti microbial susceptibility pattern of the bacterial uropathogens isolated from the children attending Gandaki Medical College Teaching Hospital and Reserch Center (GMC) Nepal. A total of 155 children aged upto 15 years were included in this study. Urine cultures were carried out and the isolates were identified by Gram staining and conventional biochemical methods. Antimicrobial susceptibility testing was performed by disk diffusion method according to the Clinical and Laboratory Standards Institute (CLSI).

RESULTS: In the present study $21.3 \%$ of the sample size, showed significant bacterial growth. E. coli was the most frequently occurring pathogen (39.40\%), followed by Proteus spp. 21.2\%, Citrobacter spp. and Streptococcus faecalis (12.1\%) Klebsiella spp. (9.1\%), and Staphylococcus aureus and Enterobacter (3.0\%). Susceptibility rate of $E$. coli were $69.2 \%$ to Gentamycin and Amikacin, $53.8 \%$ to Norfloxacin, $38.4 \%$ to Nalidixic acid and Norfloxacin.

CONCLUSIONS: Pediatric urine culture isolates were becoming increasingly resistant to commonly used antibiotics. Finally, we suggest that empirical antibiotic selection should be based on knowledge of the local prevalence of bacterial organisms and antibiotic sensitivities rather than on universal guidelines.

KEY WORDS: Urinary tract infection, Antimicrobial susceptibility, Gram positive, Gramnegative

Article submitted 25 July. Reviewed 15 August. Author correction 23 August. Final version accepted 29 August 2013. 


\section{INTRODUCTION}

Urinary tract infections (UTI) in children are usually associated with high morbidity and long term complications if they are not treated in the beginning. The incidence varies according to age, races and sex of children. ${ }^{1,2}$ UTI $(25.6 \%)$ is common in male children under the age of one year. ${ }^{3}$ UTI occurs in $1 \%$ of boys and $3-5 \%$ of girls. ${ }^{4}$ It is shown that $7 \%$ of girls and $2 \%$ of boys will have asymptomatic, culture confirmed UTI by six years of age. ${ }^{5}$ Symptoms of UTI may be minimum and non specific in infants and small children. ${ }^{6}$ The prevalence of UTI in febrile infants is greater with younger age, with a range of nearly $7 \%$ among the febrile newborn.

Majority of UTI in children result due to ascending infection, although hematogeneous spread may be more common in the first year of life. Individual differences in susceptibility to UTI may be due to host factors such as production of urethral and cervical IgA antibodies as well as other factors that influence bacterial adherence to the introitus and the urethral epithelium. ${ }^{8}, 9$ Congenital anomalies of the urinary tract such as posterior urethral valve, vesico-ureteric reflux, ureteric duplex, etc., are also well known causes of UTI in children. ${ }^{8}$

Recognition of UTI in children should be made as early as possible to prevent from high morbidity and long term complications like renal scarring, hypertension, and chronic renal failure. ${ }^{6}$ Investigation of early UTI are of very importance. ${ }^{10}$ Escherichia coli constituted for $93.3 \%$ followed by Proteus spp. Klebsiella spp., Citrobacter spp., Staphylococcus aureus and others. ${ }^{11}$

In recent years, widespread use of antibiotics has been resulted in an increasing incidence of antibiotic resistance among the urinary tract pathogens all over the world. Worldwide, emerging of antibiotic resistance is increasing among the urinary pathogens. ${ }^{12,13}$ The increase in resistance of microorganisms to antimicrobial agents, especially in hospitalized patients, demands rapid identification of the pathogen..$^{14,15,16}$ Early information enables the selection of the appropriate antibiotic prior to the results of susceptibility tests and may thereby prevent outbreaks. ${ }^{17}$ The aim of the microbiology laboratory in the management of urinary tract infection is to reduce morbidity and mortality through accurate and timely diagnosis with appropriate antimicrobial sensitivity testing. This study was carried out to see the sensitivity pattern of uropathogens in the children.

\section{MATERIALS AND METHODS}

This cross-sectional study was carried out in the Department of Microbiology, Gandaki Medical College Teaching Hospital and Reserch Center (GMC) Pokhara, Kaski from to June 2005 to May 2006.

The clean-catch mid-stream urine sample were collected $^{18}$ only from new suspected UTI patients aging upto 15 years from outdoor and indoor patients of GMC Hospital and examined under microscope. ${ }^{19}$ Samples showing $>5$ pus cell/HPF were included in the study ${ }^{20}$ and cultured into MacConkey Agar, CLED agar and sheep Blood Agar media. ${ }^{21,22}$ Mueller-Hinton agar was used for susceptibility testing and Nutrient agar for preservation of organism. All isolates were tested for antimicrobial susceptibility against different antibiotics using the disc diffusion method..$^{23,24}$ The zone size was translated into the 3 susceptibility categories, namely Susceptible (S) intermediate (I) and Resistant (R) was done according to CLSI. ${ }^{25}$

\section{RESULTS}

Out of 115 children, 33 were found to be culture positive. Fifteen cases that showed mixed growth were excluded in the present study. The age and gender of children from whom the culture positive samples were collected are shown in table 1 . Majority of the cases were of less than 10 years of age. Maximum number of cases was seen in age group 6-10 years of age, where males were 9 and females were 4 and majority of female culture positive cases were in age group 2-5 years.

Table 1. Age and gender wise distribution of children

\begin{tabular}{|c|c|c|c|}
\hline \multirow[t]{2}{*}{ Age (years) } & \multicolumn{2}{|c|}{ Sex } & Total \\
\hline & Male & Female & \\
\hline$<2$ & 1 & 1 & 2 \\
\hline $2-5$ & 4 & 8 & 12 \\
\hline $6-10$ & 9 & 4 & 13 \\
\hline $11-15$ & 3 & 3 & 6 \\
\hline Total & 17 & 16 & 33 \\
\hline
\end{tabular}

E. coli $(39.4 \%)$ was the most commonly isolated organism with majority in female than that of male followed by Proteus spp. (21.2\%), Citrobacter ssp. and Streptococcus fecalis (12.1\%), Klebsiella spp. $(9.1 \%)$ and staphylococcus aureus and Enterobacter spp. (3\%). Streptococcus fecalis was found to be more frequent among male than female.

\section{DISCUSSION}


Among 155 urine samples tested 33 (21.30\%) cultures showed single type of growth, 15 showed mixed type of growth which were not included in the present study and rest of them no growth. Out of all $21.30 \%$ were cultures positive in our study, Malla et al. (39.5\%), ${ }^{26}$ Taneja et al $(28.3 \%)^{27}$ Rai et al. $(28.6 \%)^{11}$ and Sohely et al $(46.6 \%),{ }^{28}$ Malla et al. $(57 \%),{ }^{29}$ which was higher than our study,lower positive rate than present study $(1.39 \%),{ }^{30}$ Jha et al, $(7.3 \%)^{31}$ and Godwin et al, Ranjbar et al $(16.2 \%){ }^{32}$ Such variations might be due to inclusion of only those having complication of renal disease in higher culture cases and lower rate positive culture due to inclusion of all children of certain locality and variation on sample size .

UTI is found to be the common problem in children and depends upon the age and sex of the children. Occurrence of UTI among male children is more than female in first year of life and female after one year of age. Present study showed equal number of cases in first year of age. Present study shows marginally high rate of UTI among male children as compared to that of female. This might be due to more preference given to son than daughter/due to the uncircumscribed cases in Nepalese society.

E. coli (39.4\%) was the commonest bacterial isolates of all positive cases followed by Proteus spp. and others. Which was somewhere near to that of Godwin et al (36.4\%), ${ }^{31}$ Ranjbar et al. (40\%). ${ }^{32}$ On the other hand present finding was lesser than the finding of GK et al (93.3\%), ${ }^{11}$ Taneja et al. (47.1\%), ${ }^{27}$ Aiyegoro et al. (52.77\%), ${ }^{33}$ and Jha B $\mathrm{K}$ et al. $(1.39 \%) .^{30}$ This variation can be due to age groups, congenital anomalies of urinary tract. ${ }^{8}$ The bacterial isolates in the present study are similar to that of Regmi et $\mathrm{al}^{34}$ and Rai et al. ${ }^{11}$
E. coli was the principal isolates showing marginally high infection among male childrens showing high susceptibility to Amikacin and Gentamycin (69.2\%) followed by Norfloxacin, Nalidixic acid and Ofloxacin. Kumari et al. $^{35}$ reported Amikacin as the most sensitive followed by Gentamycin, in agreement to the present study. Others, Malla et al. ${ }^{29}$ from Pokhara, Das et al from western part of Nepal showed Amikacin was the most sensitive drug.

Proteus spp. was found to be the causative agent to about $21.2 \%$ of cases in agreement to that of Godwin et al and close to that of Rai et al. ${ }^{11}$ and Shrestha et al. ${ }^{36}$ It was found higher than the findings of Younis $\mathrm{N}$ et al., ${ }^{37}$ Kalantar E et al., ${ }^{38}$ Taneja $\mathrm{N}$ et al., ${ }^{27}$ Aiyegoro et al., ${ }^{33}$ and Sohley et $\mathrm{al}^{28}$

Proteus spp. was found to be sensitive to Amikacin $(100 \%)$ followed by Gentamycin, Ciprofloxacin \& Ofloxacin by $(42.8 \%)$ and Norfloxacin and Nalidixic acid by $(28.5 \%)$ as reported by Malla et al. ${ }^{29}$ with differences in resistance differences.

In the present study Amikacin and Gentamycin have the highest sensitivity. This study suggests to include in the empirical formulae of the hospital.

\section{CONCLUSIONS}

Enteriobacteriaceae family was found to be the most common pathogen that causes UTI among the children. UTI is a significant problem in children and still it is a major cause of high morbidity and

Table 1. Antibiotic susceptibility pattern of different uropathogens isolated

\begin{tabular}{|c|c|c|c|c|c|c|c|c|}
\hline \multirow[b]{2}{*}{ Organisms } & \multicolumn{8}{|c|}{ Antibiotics Susceptibility (\%) } \\
\hline & 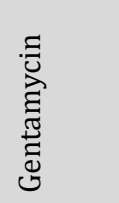 & 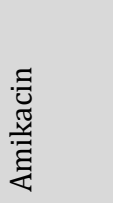 & 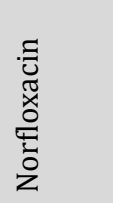 & 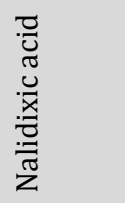 & 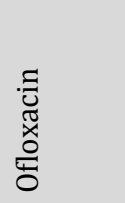 & 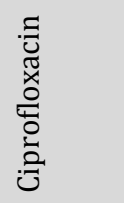 & 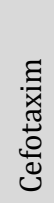 & \\
\hline E. coli & 69.2 & 69.2 & 53.8 & 38.4 & 38.4 & - & & - \\
\hline Proteus spp. & 85.7 & 100 & 28.5 & 28.5 & 42.8 & 42.8 & & - \\
\hline Citrobacter spp. & 75 & 100 & 75 & - & 25 & 25 & & - \\
\hline $\begin{array}{l}\text { Streptococcus } \\
\text { feacalis }\end{array}$ & 50 & 100 & 75 & - & - & 50 & & 50 \\
\hline Klebsiella spp. & 85.7 & 100 & 28.5 & - & - & 42.8 & & - \\
\hline
\end{tabular}

"-“, not tested 
mortality in developing world. Regular monitoring in large scale is required at regular intervals in order to identify the reliable information about the resistance patterns of urinary pathogen. Finally it is suggested that empirical antibiotic selection should be based on the knowledge of local prevalence of bacteria and their sensitivities rather than the Universal guidelines.

CONFLICT OF INTEREST: None to declare.

FINANCIAL INTEREST: None to declare.

\section{REFERENCES}

1. Bickerton MW, Ducket JW. Urinary tract infection in pediatric patients, American Urological Association, Houston; Texas1985.

2. Shaw KN, Gorelick M, McGowan KL, Yakscore NM, Schwartz JS. Prevalence of urinary tract infection in febrile young children in the emergency department. Pediatr 1998;102:16-21.

3. Taneja N, Chatterjee SS, Singh M, Singh S, Sharma M. Pediatric urinary tract infections in a tertiary care center from north India. Indian J Med Res;131:101-105.

4. Elder, JS. Urinary tract infections. In: Kliegman RM, Behrman, RE, Jenson, HB, Stanton BE, editors. Nelson Textbook of Pediatrics. Philadelphia: Saunders 2007;2223-2228.

5. Marild S, Jodal U. Incidence rate of first-time symptomatic urinary tract infection in children under 6 years of age. Acta Paediatr 1998;87:549-552.

6. Chon CH, Lai FC, Shorthffe LM. Pediatric urinary tract infections. Pediatr Clin North Am 2001;48:1447-1459.

7. Bachur R, Harper MB. Reliability of the urinalysis for predicting urinary tract infections in young febrile children. Arch Pediatr Adolesc Med 2001;155:60-65.

8. Roberts JA. Factors predisposing to urinary tract infections in children. Pediatr Nephrol 1996;10:517-522.

9. James-EllisonMY, Roberts R, Verrier-JonesK, WilliamsJD, TopleyN. Mucosal immunity in the urinary tract: Changes in SIgA, FSC and total IgA with age and urinary tract infection. Clin Nephrol 1997;48:69-78.

10. Watson AR. Disorders of the urinary syastem. In: Campbell AG, McIntoshN editors. Forfar and Arneil's Textbook of Pediatrics. Churchill Livinstone.1998: 949-56. 11. Rai GK, Upreti HC, Rai SK, Shah KP, Shrestha RM. Causative agents of urinary tract infections in children and their antibiotic sensitivity pattern: a hospital based study. JNepal Med Coll 2008;10:86-90.

12. Kahlmeter G. An international survey of the antimicrobial susceptibility of pathogens from uncomplicated urinary tract infections: the ECO-sens project. J Antimicrob Chemother 2003:51:69-76.

13. Runehagen R, Kahlmeter G. A 10- year study of the consumption of quinolones, trimethoprim and mecillinam in relation to the development of antimicrobial resistance in a large number of species.(2002) Poster417. ECCMID, Milan, Italy.

14. Ashkenizi S, Even-Tov S, Samra Z, Dinari G. Uropathogens of various childhood populations and their antibiotic susceptibility. J Pediatr Infect Dis 1991;10:742-746.

15. Marray BE. Problems and mechanisms of antimicrobial resistance. Infect Dis Clin North Am 1990;3:423-39

16. Alon U, Davidi G, Brant M, Merzbach D. Five year survey of changing patterns of susceptibility of bacterial uropathogens to Trimethoprimsulphamethoxazole and other antimicrobial agents. Antimicrob Agents Chemother 1987;31:126-128.

17. Schaberg DR, Culvar DH, Gaynes RP. Major trend in the microbiology and etioloigy of nosocomial infections. Am J Med 1991;91(Suppl3B):S72-725.

18.Forbes BA, Sahm DF, Weissfeld AS. Laboratory cultivation and isolation of bacteria. In Bailey \& Scott's Diagnostic Microbiology, 10 $0^{\text {th }}$ ed. St. Louis: Missouri; Mosby;1998;150-166.

19 Brooks GF, Butel JS, Morse SA. Principles of Diagnostic Medical Microbiolgy. In Jawetz, Melnick,\& Adelberg edits Medical Microbiology. 22 $2^{\text {nd }}$ ed. New Delhi: McGraw-Hill;2002;596-622.

20. Fuller CE, Threatte GA, Henry JB. Basic Examination of Urine. In Henry JB, Davey FR, Herman CJ et al., edits Clinical. Diagnosis and Management by Laboratory Methods. 20 th ed. WB Saunders Company: Philadelphia;2001;367-402.

21. Collee JG, Marr W. Specimen collection, culture containers and media. In Collee JG, Fraser AG, Marmion BP, Simmons A. edits Mackie \& McCartney Practical Medical Microbiology, 14th ed. Churchill Livingstone: New York;1996;85-111.

22. Lakshmi V, Satheeshkumar T, Kulkarni G. Utility of Urochrom ii- A Chromogenic Medium for Uropathogens. Ind J Med Microbiol 2004;22:153-158.

23. Cheesbrough M. Antimicrobial sensitivity testing. In District Laboratory Practice in Tropical Countries (Part 2). UK: Cambridge University Press:2000;132-1342.

24. Vandepitte J, Engback K, Piot P, Heuck CC. Basic Laboratory Procedures in clinical Bacteriology. WHO: Geneva:1992;47-49.

25. NCCLS. Performance standards for antimicrobial susceptibility disc testing. National Committee for Clinical Laboratory Standards 1987, Villanova, PA, USA, Secon International Supplement: M100-S2.

26. Malla T, Malla KK, ThapaliaA, Sharma MS. An overview of renal diseases in children in Pokhara. J Nepal Paediatr Soc 2007;27:75-78.

27. Taneja N, Chatterjee SS, Singh M, Singh S, Sharma M. Pediatric urinary tract infections in a tertiary care center from north India. Indian J Med Res 2010:131:101-105.

28. Sharmin S S, F Alamgir, Khanam F, Saleh AA. Antimicrobial sensitivity pattern of uropathogens in children. Bangladesh Society of Medical 
Microbiologists. Bangladesh J Med Microbiol 2009;03:1822.

29. Malla KK, Sarma MS, Malla T,Thapalial A. Clinical profile bacterial isolates and antibiotic susceptibility patterns in urinary tract infection in children- hospital bases Study. J Nepal Paediatr Soc 2008;28:52-61.

30. Jha BK,Singh YI. Prevalence of asymptomatic bacteriuria in school going children in Pokhara valley. Kathmandu Uni Med J 2007;5:81-84.

31. Godwin TJ, Gyuse AN, Odey FI, et al. A survey of antimicrobial susceptibility patterns of bacterial isolates from community acquired significant bacteriuria among pre-school children in a municipality in calabar. Int J Biol Med Res 2010;1:172-176.

32. Ranjbar R, Haghi-Ashtian MT, JonaidiJafari N, Abedini M. The prevalence and antimicrobial susceptibility of bacterial uropathogens isolated from pediatric patients. Iranian J Public Health 2009;38:134-138.

33. Aiyegoro OA, Igbinosa 00, Ogunmwonyi IN, Odjadjare $\mathrm{EE}$, Igbinosa $\mathrm{OE}, \mathrm{OkohA} \mathrm{I}$. Incidence of urinary tract infections (UTI) among children and adolescents in Ile-Ife, Nigeria. African J Microbiol Res 2007;1:113-119.

34. Regmi SC, Ghimire P, Shrestha S. Rapid diagnostic tests in diagnosis of urinary tract infection. J Nepal Assoc Med Lab Sci 2004;6:32-34.

35. Kumari N, Ghimire G, Gharti Magar JK, Mohapatra TM, Rai A. Antibiogram pattern of isolates from UTI cases in Eastern part of Nepal. J Nepal Med Coll 2005;7:116-118 36. Shrestha B, Basnet RB, Shrestha P, Shahi P. Prevalence of urinary tract infection in female patients attending Kathmandu Model Hospital. J Nepal Assoc Med Lab Sci 2005;7:10-14.

37. Younis N, Quol K, Al-Momani T, Al-Awaisheh F, AlKayed D. Antibiotic resistance in children with recurrent or complicated urinary tract infection. J Nepal Med Assoc 2009;48,1:14-19

38. Enayatollah K, Mohammad M, Hamid L, Naser R. Prevalence of urinary tract pathogens and antimicrobial susceptibility patterns in children at hospitals in Iran. Iranian J Clin Infect Dis 2008;3:149-153

\section{Citing this article}

Aljumaili ZKM, Gautam G, Regmi S, magar NT, Subedi B, Sharma T, Regmi SM. Occurrence of urinary tract infection among children attending Gandaki Medical College Teaching Hospital and Research Center, Pokhara, Nepal. Int J Infect Microbiol 2013;2(3):82-86. 